\title{
EVALUASI PENGGUNAAN SISTEM INFORMASI AKADEMIK POLITEKNIK NEGERI SRIWIJAYA
}

\author{
RD Kusumanto ${ }^{1}$, Irma Salamah ${ }^{2}$, A. Rahman ${ }^{3}$ \\ Politeknik Negeri Sriwijaya \\ Jl. Srijaya Negara Bukit Besar Palembang, Indonesia \\ e-mail:manto_6611@yahoo.co.id ${ }^{1}$,irma.salamah@yahoo.com², a_rahman@polsri.ac.id ${ }^{3}$
}

\begin{abstract}
ABSTRAK
Sistem Informasi Akademik merupakan sistem pendukung penyelenggaraan pendidikan, sehingga dalam proses pendidikan dapat menyediakan layanan informasi yang lebih baik kepada mahasiswanya. Sistem Informasi Akademik Polsri dibuat untuk dapat membantu mempermudah kinerja dari pihak akademik dan mahasiswa dalam mengorganisir jadwal mengajar dosen, kehadiran dosen dan rekapitulasi nilai sehingga perlu dilakukan evaluasi bagaimana penggunaan mahasiswa pada sistem informasi akademik (SISAK) Politeknik Negeri Sriwijaya. Penerapan SISAK Polsri memerlukan evaluasi, diantaranya terkait dengan tingkat penggunaan sistem tersebut. Tujuan dari penelitian ini adalah untuk mengevaluasi penggunaan sistem informasi akademik Polsri dalam mendukung proses administrasi dari sisi kegunaan, kemudahan penggunaan, dan ketersediaan jaringan. Evaluasi SISAK Polsri menggunakan metode Technology Acceptance Model (TAM) untuk mengetahui faktor-faktor tersebut. Data dikumpulkan dengan menggunakan teknik survei dan dianalisis dengan menggunakan metode statistik multivariate. Hasil penelitian menunjukkan perceived usefulness dan perceived ease of use tidak berpengauh terhadap actual usage SISAK Polsri, sedangkan perceived availability berpengaruh terhadap actual usage SISAK Polsri
\end{abstract}

Kata Kunci : TAM, sistem informasi akademik, Polsri

\begin{abstract}
Academic Information System is a system of supporting the implementation of education, so that in the education process can provide better information services to students. The Police Academic Information System was created to be able to help facilitate the performance of academics and students in organizing lecturers' teaching schedules, lecturer attendance and value recapitulation so that it is necessary to evaluate how students are used in the Sriwijaya Polytechnic Academic Information System (SISAK). The application of SISAK Polsri requires an evaluation, including related to the level of use of the system. The purpose of this study is to evaluate the use of Polsri academic information systems in supporting administrative processes in terms of usability, ease of use, and network availability. SISAK's evaluation uses the Technology Acceptance Model (TAM) method to determine these factors. Data were collected using survey techniques and analyzed using multivariate statistical methods. The results showed that perceived usefulness and perceived ease of use do not affect the actual usage of SISAK Polsri, while perceived availability affected the actual usage of SISAK Polsri.
\end{abstract}

Keywords: TAM, information academic system, Polsri

\section{Pendahuluan}

Pelayanan dalam suatu organisasi memegang peranan yang cukup penting, oleh karena itu saat ini semakin banyak organisasi-organisasi yang mengalihkan perhatiannya kepada pengguna dan kemudian mengorientasikan kinerjanya pada mutu pelayanan. Pelayanan yang dilakukan oleh setiap organisasi merupakan investasi yang tak ternilai harganya. Untuk itu sistem pelayanan yang diterapkan harus mempunyai kualitas yang baik serta mempunyai tingkat keoptimalan yang tinggi [1].

Perkembangan Sistem Informasi dan Teknologi Informasi (SI/TI) yang sangat pesat pada saat ini, telah dianggap juga sebagai sumber daya yang sangat penting bagi organisasi baik organisasi pemerintah maupun organisasi swasta [2]. Sistem Informasi dan Teknologi Informasi (SI/TI) tidak hanya berperan sebagai suatu dukungan semata, namun juga telah berperan sebagai key operational, high potential, peran 
strategis, dan dapat dimanfaatkan untuk mendukung efektivitas, efisiensi, dan produktivitas dalam organisasi [3]. Pada lingkungan perguruan tinggi, pemanfaatan teknologi informasi dan komunikasi dapat diwujudkan salah satunya dalam bentuk Sistem Informasi Akademik.

Masalah yang sering terjadi pada perguruan tinggi pada umumnya adalah keterbatasan pengolahan yang merupakan salah satu proses interaksi antara bagian internal perguruan tinggi ataupun lembaga pendidikan yang mengolah data dengan proses serta prosedur-prosedur tertentu dengan user yang dalam hal ini adalah mahasiswa. Kesulitan yang sering terjadi pada bagian internal perguruan tinggi adalah banyaknya proses pengolahan data yang harus dilakukan dalam waktu yang singkat. Contohnya, pengolahan data mahasiswa yang mengambil mata kuliah dan kelas. Pada pengolahan data tersebut akan di dapat data-data transaksi berupa, data absensi, data mata kuliah, data transkrip nilai, data jadwal ujian, data biaya pembayaran (status pembayaran mahasiswa), data dosen beserta atribut data gaji yang merupakan bagian dari sistem keuangan yang diterapkan pada sisi keuangan. Dengan adanya suatu sistem, diharapkan pengolahan data antara user dan bagian sistem akademik yang menerima inputan dari mahasiswa serta transaksi kegiatan perkuliahan dan kegiatan administrasi antara mahasiswa dan perguruan tinggi tersebut dapat berlangsung dengan baik [4].

Sistem Informasi Akademik bertujuan untuk mendukung penyelenggaraan pendidikan, sehingga dalam proses pendidikan dapat disediakan layanan informasi yang lebih baik kepada mahasiswanya. Sistem informasi akademik merupakan sebuah sistem yang dibuat dan dikembangkan dalam rangka mengelola data-data serta penjadwalan kegiatan akademik sehingga memberikan kemudahan kepada pengguna dalam kegiatan akademik kampus baik dengan intranet maupun internet. Namun demikian penerapan sistem informasi akademik tetap memerlukan evaluasi, apakah sistem informasi dan teknologi tersebut dapat diterima oleh user dengan baik dan apakah pengguna sistem merasa puas dengan infomasi dan kinerja dari sistem tersebut [5].

Politeknik Negeri Sriwijaya (Polsri) merupakan salah satu perguruan tinggi yang telah menerapkan teknologi informasi (TI) dalam mendukung operasional pembelajaran. Penggunaan TI akan meningkatkan efektifitas operasional dalam pembelajaran.

Sistem Informasi Akademik (SISAK) berbasis web yang dikenalkan kepada dosen Politeknik Negeri Sriwijaya dalam proses pendidikan memberikan dampak besar terhadap mahasiswa. Sistem Informasi Akademik berbasis web diterapkan untuk membantu penyelenggaraan kegiatan akademik bagi dosen dan mahasiswa Polsri. Dosen dapat melihat jadwal mengajar dan melakukan proses input nilai UTS dan UAS pada semester yang berjalan. Sedangkan mahasiswa selain dapat melihat jadwal mahasiswa khususnya perangkat kelas juga dapat mengisi kehadiran dosen.

Penelitian ini akan dilakukan dengan menggunakan Technology Acceptance Model (TAM) yang digunakan untuk mengukur penerimaan sistem informasi yang dikenalkan pertama kali oleh Davis (1986). Dimana teori ini dikembangkan dari Theory of Reasoned Action atau TRA oleh Ajzen dan Fishbein (1980). Model penelitian ini merupakan model penelitian yang paling luas digunakan untuk meneliti perilaku pengguna dalam menerima dan menggunakan teknologi, karena model ini merupakan model yang sederhana tetapi dianggap cukup valid. Selain itu memang dibutuhkan suatu model yang dapat menjadi acuan untuk membuat sistem teknologi informasi dapat diterapkan secara sukses di suatu organisasi.

Secara teoritis dan praktis Technology Acceptance Model (TAM) merupakan model yang dianggap paling tepat dalam menjelaskan bagaimana user (pengguna) menerima sebuah sistem. [6] dalam bukunya Sistem Informasi Keperilakuan yang mengatakan bahwa : "TAM telah diuji dengan banyak penelitian dan hasilnya sebagian besar mendukung dan menyimpulkan bahwa TAM merupakan model yang baik. Bahkan TAM telah banyak diuji dibandingkan dengan model yang lain misalnya dengan Theory Reasoed Action (TRA) dan Theory Planned Behavior (TPB) dan hasilnya juga konsisten bahwa TAM cukup baik.

Tujuan dari TAM adalah memberikan penjelasan tentang penentuan penerimaan komputer secara umum, memberikan penjelasan tentang perilaku/sikap pengguna dalam suatu populasi [6]. TAM menyatakan bahwa behavioral intension to use ditentukan oleh dua keyakinan yaitu: pertama, perceived usefulness yang didefinisikan sebagai sejauh mana seseorang yakin bahwa menggunakan sistem akan meningkatkan kinerjanya. Kedua, perceived ease of use yang didefinisikan sebagai sejauh mana seseorang yakin bahwa penggunaan sistem adalah mudah. TAM juga menyatakan bahwa dampak variabel-variabel eksternal seperti (karakteristik sistem, proses pengembangan dan pelatihan) terhadap intension to use 
adalah dimediasi oleh perceived of usefulness dan perceived ease of use. Konsep TAM juga menyatakan bahwa perceived usefulness dipengaruhi oleh perceived ease of use.

Beberapa penelitian telah dilakukan oleh para peneliti untuk mengevaluasi tingkat keberhasilan penerapan teknologi informasi dengan mengukur tingkat penerimaan dan kepuasan pengguna akhir dari sistem tersebut.

Penelitian sistem informasi akademik dengan menggunakan metode UTAUT dilakukan oleh [7]. Penelitian ini bertujuan untuk mengetahui pengaruh variabel UTAUT terhadap minat mahasiswa untuk melakukan akses ke dalam Sistem Informasi Kemahasiswaan di STKIP PGRI Pacitan dan memberikan rekomendasi perbaikan sistem kedepannya. Hasil penelitian ini adalah bahwa variabel performance expectancy, effort expectancy, hedonic motivation, behavioral intention dan facilitating condition berpengaruh signifikan

positif. Variabel ini mampu mempengaruhi penerimaan sistem sebesar $92,7 \%$.

Selain dengan UTAUT penelitian system informasi akademik juga dilakukan dengan menggunakan metode ERP succes model. Penelitian ini dilakukan oleh [8] yang dalam penelitianya bahwa kesuksesan system infpormasi akademik diukur dari variabel kualitas informasi, kualitas sistem dan kualitas layanan. Dijelaskan bahwa ketiga variabel tersebut berpengaruh terhadap kesuksesan SIAKAD.

Penelitian [9] menemukan bahwa tingkat penerimaan user terhadap penerapan SiAkad dikatakan baik. Faktor-faktor yang mempengaruhi tingkat penerimaan SiAkad untuk variabel TAM yaitu persepsi pengguna terhadap kemudahan (perceived ease of use) dan persepsi pengguna terhadap kegunaan/manfaat (perceived usefulness), sedangkan sikap pengguna terhadap penggunaan (attitude toward using) tidak mempengaruhi tingkat penerimaan SiAkad berdasarkan uji ke-sesuaian. Untuk variabel Usability, yang tidak mempengaruhi tingkat penerimaan SiAkad ada-lah error sehingga pengguna masih sulit untuk menemukan informasi dalam suatu situs web.

Penelitian [10] dengan menggunakan model Technology Acceptance Model (TAM) yaitu sebuah model penerimaan teknologi informasi. Variabel Kemanfaatan dan Kemudahan Penggunaan terbukti tidak dapat mempengaruhi kepuasan pengguna sebagai pemakai akhir penggunaan e-learning. Sedangkan analisis dengan menggunakan model End User Computing Satisfaction (EUCS) diperoleh bahwa variabel Bentuk (format), dan variable kemudahan (ease) dapat mempengaruhi kepuasan pengguna sebagai pemakai akhir dalam penggunaan e-learning. Namun untuk variabel Kemanfaatan (usefulness), kemudahan penggunaan (ease of use), Isi (content), Keakuratan (accuracy), dan ketepatan waktu (timeli-ness) tidak mempengaruhi kepuasan pengguna sebagai pemakai akhir dalam penggunaan $e$-learning.

Penelitian Evaluasi Penerapan SIAKAD Politeknik Negeri Madiun dilakukan oleh [5] dengan menggunakan model Technology Acceptance Model (TAM) untuk mengetahui tingkat persepsi penerimaan pengguna terhadap SIAKAD dan End-User Computing Satisfaction (EUCS) untuk mengetahui tingkat kepuasan pengguna. Hasil penelitian ini menunjukan bahwa SIAKAD PNM dapat diterima oleh pengguna dilihat dari aspek persepsi kemudahan dan persepsi kemanfaatan baik secara individual maupun secara simultan. Sedangkan tingkat kepuasan pengguna secara simultan terpenuhi dari aspek content, accuracy, format, ease dan timeline, tetapi secara individual tidak terpenuhi dari aspek accuracy, format, dan timelines.

Penelitian [11] membuktikan bahwa sikap pengguna sistem informasi akademik atas perilaku penggunaan sistem informasi berpengaruh terhadap perubahan sikap pengguna sistem informasi akademik. Dengan demikian dapat dikatakan bahwa isi (content), kemudahan dalam penggunaan (easy to use), format dan penyajian tepat waktu (timeliness) berpengaruh signifikan terhadap sikap dan sikap penggunasistem informasi akademik berpengaruh signifikan terhadap perilaku pengguna sisteminformasi akademik. Dan dapat dikatakan juga bahwa keakuratan (accuracy) tidak berpengaruh signifikan terhadap sikap pengguna sistem informasi akademik. Agar penggunaan sistem informasi akademik dapat berhasil dengan optimal maka disarankan agar dapat menjaga format sistem informasi akademik dengan baik dan meningkatkan peranan penyajian tepat waktu (timeliness) sistem informasi akademik dengan melakukan perbaikan secara konstruktif oleh pihak perguruan tinggi.

Dari paparan diatas penulis ingin mengevaluasi sejauh mana tingkat keberhasilan penggunaan Sistem Informasi Akademik Polsri dalam menunjang proses akademik di lingkungan Politeknik Negeri Sriwijaya. Salah satu cara untuk mengetahui tingkat keberhasilan dalam penggunaan teknologi informasi dapat diketahui dengan mengukur sejauh mana tingkat penerimaan pengguna terhadap teknologi yang diterapkan tersebut. 


\section{KAJIAN PUSTAKA}

\subsection{Penerimaan Sistem Informasi}

Penentu kepuasan dari pengguna adalah mutu dari sistem dan informasi serta ketergunaan sistem tersebut didasarkan pada kebutuhan dan harapan pengguna. Apabila harapan dan kebutuhan dari pengguna sudah dipenuhi serta mutu informasi dan sistem yang disediakan bernilai baik pada akhirnya akan mendukung kesuksesan dari suatu sistem informasi itu sendiri. Kesuksesan suatu sistem informasi akan berdampak kepada organisasi, dimana beberapa faktor penentunya adalah mutu sistem dan mutu informasi. Kedua hal tersebut (mutu dari sistem dan informasi) akan berpengaruh langsung kepada kepuasan pengguna dan seberapa seringnya sistem tersebut digunakan [12]. Kepuasan dan seberapa seringnya sistem tersebut digunakan akan berdampak secara langsung pada individu pengguna sistem, apakah pengguna akan mendapat suatu pengetahuan dan pengalaman baru atau dapat mengubah kebiasan pengguna itu sendiri hingga pada akhirnya akan berdampak pada suatu organisasi [13].

Untuk mengetahui apakah sistem yang telah diterapkan sudah diterima atau belum oleh pengguna, maka diperlukan analisis untuk mengukur penerimaan sistem informasi. Ada beberapa model untuk mengukur penerimaan teknologi informasi seperti Theory of Reason Action (TRA), Technology Acceptance Model (TAM), End-User Computing Satisfaction (EUCS), and Task Technology Fit (TTF) Analysis.

\subsection{Teknologi Acceptance Model (TAM)}

Dalam TAM terdapat dua konstruk utama yaitu persepsi kemudahan (perceived ease of use) dan persepsi kegunaan (perceived usefulness) yang keduanya menjelaskan aspek perilaku pengguna. Model TAM menjelaskan bahwa persepsi pengguna akan menentukan sikap pengguna terhadap pemanfaatan teknologi informasi. Model ini mendeskripsikan bahwa penerimaan penggunaan teknologi informasi dipengaruhi oleh dua konstruk atau parameter utama di atas. Davis (1989: 333) juga berpendapat bahwa model TAM ini menunjukkan bahwa persepsi kegunaan dan persepsi kemudahan adalah suatu kepercayaan terhadap adanya teknologi baru yang mempengaruhi sikap seseorang terhadap penggunaan teknologi.

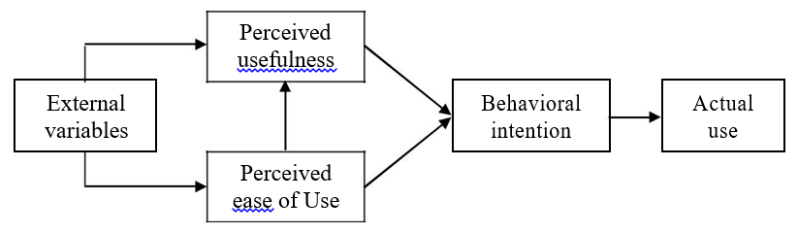

Gambar 1. Model Penerimaan Teknologi Davis (1989)

Menurut Davis, TAM menfokuskan pada alasan pengguna untuk menerima atau menolak teknologi infomasi dan bagaimana cara untuk meningkatkan penerimaan suatu teknologi (Silva \& Dias, 2007: 78). Davis menyebutkan ada 5 konstruk dalam TAM.

Penjabaran dari konstruk-konstruk di atas adalah sebagai berikut [6]:

1. Persepsi kemudahan penggunaan (Perceived ease of use).

Definisi persepsi kemudahan (perceived ease of use) menurut [14] adalah: "the degree to which a person believes that using a particular system would be free of physical and mental efforts".

Persepsi kemudahan adalah tingkat kemudahan yang dirasakan seseorang dalam menggunakan teknologi.

\section{Persepsi Kegunaan (Perceived Usefulness).}

[14] mendefinisikan persepsi kegunaan (perceived usefulness) yaitu: the degree to which a person believes that using particular system would enhance his or her job performance. Persepsi kegunaan (perceived usefulness) dapat diartikan sebagai suatu tingkatan dimana seseorang percaya bahwa suatu sistem tertentu akan dapat meningkatkan prestasi kerja atau kinerja pengguna sistem tersebut.

\section{Sikap terhadap pengunaan teknologi (Attitude Toward Using),}

Definisi sikap penggunaan (attitude toward behavior) menurut [14] yaitu: an individual's positive or negative feelings about performing the target behavior. Definisi tersebut dapat diartikan sebagai perasaan pengguna, baik positif maupun negatif untuk melakukan perilaku yang sudah ditentukan. 


\section{Minat perilaku mengunakan teknologi (Behavioral Intention to Use),}

Behavioral In ten ini didefinisikan sebagai minat (keinginan) seseorang secara sadar untuk melakukan atau tidak melakukan suatu perilaku di waktu yang akan datang yang telah ditentukan sebelumnya.

5. Penggunaan teknologi sesungguhnya (Actual Technology Use),

Hal ini diukur dengan jumlah waktu yang digunakan untuk berinteraksi dengan teknologi dan frekuensi penggunaan teknologi tersebut. Penggunaan sistem sesungguhnya (actual system use) merupakan kondisi nyata penggunaan sistem.

\subsection{Persepsi Ketersediaan Layanan (Perceived Service Availability)}

Persepsi ketersediaan layanan adalah persepsi pengguna bahwa system yang digunakan mampu menyediakan koneksi dan tepat waktu. Persepsi ketersediaan layanan diukur dengan indikator dapat menggunakan teknologi kapan dan dimana saja, teknologi dapat dengan mudah diakses dan portable, teknologi tersedia untuk digunakan kapanpun dibutuhkan [15], [16], [17].

\subsection{Sistem Informasi Akademik}

Sistem Informasi Akademik adalah suatu sistem yang dirancang untuk keperluan pengeloaan datadata akademik dengan penerapan teknologi komputer baik hardware maupun software sehingga seluruh proses kegiatan akademik dapat terkelola menjadi informasi yang bermanfaat dalam pengelolaan manajemen perguruan tinggi dan pengambilan keputusan-keputusan bagi pengambil keputusan atau top manajemen di lingkungan perguruan tinggi. Sistem ini bertujuan untuk mendukung penyelenggaraan pendidikan, sehingga perguruan tinggi dapat menyediakan layanan informasi yang lebih baik dan efektif kepada komunitasnya, baik didalam maupun diluar perguruan tinggi tersebut melalui internet. Berbagai kebutuhan dalam bidang pendidikan maupun peraturan yang melingkupinya sedemikian tinggi, sehingga pengelolaan akademik dalam suatu lembaga pendidikan menjadi pekerjaan yang sangat menguras waktu, tenaga dan pikiran. Oleh sebab itu, sistem informasi akademik dibangun untuk menjawab secara langsung masalah maupun kebutuhan perguruan tinggi terhadap pengelolaan akademik tersebut secara cepat dan tidak melelahkan [4].

Sistem informasi akademik merupakan suatu sistem yang dibuat untuk mempermudah kegiatan administrasi akademik di kampus, yang mana kesemuanya diatur secara daring (online). Beberapa contoh kegiatan yang bersifat administratif di kampus adalah Penerimaan Mahasiswa Baru (PMB), penyusunan kurikulum dan jadwal kuliah, mengisi Kartu Rencana Studi (KRS), mengisi nilai (untuk dosen), mengelola data dosen, karyawan, dan mahasiswa, dsb [18].

\section{METODE PENELITIAN}

\subsection{Populasi Dan Sampel}

Populasi dalam penelitian ini adalah mahasiswa Politeknik Negeri Sriwijaya yang memiliki akses untuk dapat login pada SISAK Polsri. Mahasiswa yang bisa login pada SISAK Polsri adalah perangkat kelas yaitu ketua kelas, wakil ketua kelas, sekretaris, dan bendahara.

Pengambilan sample dilakukan dengan teknik convenience sampling. Defenisi convenience sampling menurut Sekaran (2006) adalah Convenience sampling reverse to the collection the information from members of population who are conveniently available to provide it. Menurut Sarwoko (2007) Convenience Sampling cara mengumpulkan informasi dari elemen- elemen populasi yang tersedia dengan tidak perlu susah payah. Sebagai contoh, penelitian yang menggunakan teman-teman sekampus, tetangga, saudara-daudara sendiri sebagai responden.

\subsection{Model dan Hipotesis Penelitian}

Model yang digunakan dalam penelitian ini adalah Technology Acceptance Model (TAM). Alasan penulis menggunakan TAM adalah karena TAM mampu memberikan penjelasan yang kuat dan sederhana untuk penerimaan teknologi informasi. Selain itu TAM merupakan model yang sangat populer dan sering digunakan untuk menjelaskan penerimaan pengguna.

Model Penelitian adalah sebagai berikut : 


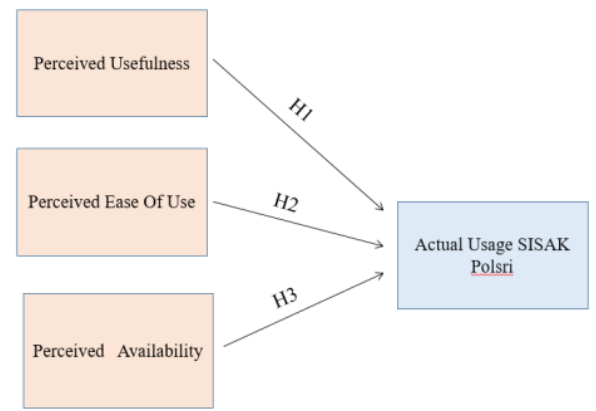

Gambar 3.1. Model Penelitian

Berdasarkan model penelitian yang dibuat, maka hipotesis penelitian adalah sebagai berikut :

H1 : perceived usefulness berpengaruh terhadap actual usage SISAK Polsri

$\mathrm{H} 2$ : perceived ease of use berpengaruh terhadap actual usage SISAK Polsri

H3 : perceived availability berpengaruh terhadap actual usage SISAK Polsri

\subsection{Pengujian Kualitas Data}

Pengukuran variabel dalam penelitian ini dilakukan dengan tujuan agar hipotesis yang diajukan dapat diuji dan pertanyaan penelitian dapat dijawab. Dua kriteria utama untuk menguji seberapa baik instrument pengukuran yang digunakan yaitu dengan uji validitas dan uji reliabilitas. Uji validitas dalam penelitian ini dilakukan dengan menghitung korelasi antar skor dengan bantuan aplikasi SPSS. Pengujian validitas juga dilakukan untuk setiap butir pertanyaan yang digunakan dalam variabel. Suatu instrument dikatakan valid jika nilai corrected item total correlation $>\mathrm{r}$ tabel [19]. Sedangkan uji reliabilitas hanya dapat dillakukan setelah suatu instrument dipastikan validitasnya. Uji reliabilitas dalam penelitian ini akan menggunakan bantuan aplikasi SPSS dengan melihat nilai koefisien Alpha atau Alpha Cronbach.suatu instrument dikatakan reliable jika nilai cronbach alpha $>6$ [20].

\subsection{Uji Asumsi Klasik}

Sebelum dianalisis data tersebut harus diuji apakah melanggar asumsi dasar yang telah ditentukan. Uji asumsi klasik dilakukan untuk melihat hubungan antar variabel dan melihat validitas dan reliabilitas yang terdiri dari uji multikolinearitas, uji autokorelasi, uji normalitas, dan uji heterokedastisitas.Uji normalitas untuk melihat apakah data terdistribusi normal (dengan grafik normal distribution), uji multikolinieritas untuk mengetahui ada atau tidaknya hubungan linier antar variable independen dalam model regresi (dengan nilai VIF < 10), uji autokorelasi untuk mengetahui ada atau tidaknya korelasi yang terjadi antara residual (tidak terjadi auto korelasi jika DW $<1$ dan DW $>3$ ) dan uji heterokedastisitas untuk melihat apakah data menyebar secara acak atau tidak (dengan grafik scatter plot).

\subsection{Pengujian Hipotesis}

Analisis varian merupakan analisis statistika yang mempunyai fungsi membedakan rerata lebih dari dua kelompok data dengan cara membandingkan variansinya. Analisis varian termasuk dalam kelompok statistic parametric. Sebagai alat statistik parametrik maka untuk dapat menggunakan rumus ANOVA terlebih dahulu perlu dilakukan pengujian asumsi analisis. Istilah mean of squares dalam ANOVA tidak lain adalah rerata kuadrat skor simpangannya yang menunjukkan variansi suatu distribusi yang diamati. Mean of squares ini diperoleh dari jumlah kuadrat skor simpangannya atau yang dikenal dengan istilah sum of squares dibagi dengan jumlah sampelnya. Untuk menguji hipotesis, ANOVA melakukan perbandingan antara variansi antar kelompok yang dikenal dengan istilah mean of squares between groups dengan variansi dalam kelompok (mean of squares within groups). Hasil perbandingan tersebut kemudian diuji signifikansinya untuk mengetahui penerimaan atau penolakan dari hipotesis yang diajukan.

Untuk menguji signifikansi masing-masing variabel bebas digunakan uji t (t-test), dengan membandingkan antara thitung dengan $t$ tabel. Apabila thitung lebih kecil dari $t$ tabel dan nilai signifikansi lebih besar dari 0,05 maka variabel bebas tidak signifikan pengaruhnya terhadap variabel terikat (variabel 
bebas tidak berpengaruh terhadap variabel terikat). Apabila t hitung lebih besar dari t tabel dan nilai signifikansi lebih kecil dari 0,05 maka variabel bebas signifikan pengaruhnya terhadap variabel terikat (variabel bebas berpengaruh terhadap variabel terikat [19].

Model regresi menurut [21] adalah :

$$
\mathbf{Y}=\mathbf{a}+\boldsymbol{\beta}_{1} \mathbf{X}_{1}+\boldsymbol{\beta}_{2} \mathbf{X}_{2}+\boldsymbol{\beta}_{3} \mathbf{X}_{3}+\mathbf{e}
$$

Dimana :

$\mathrm{Y}=$ behavioral intention

a $=$ konstanta

$\beta_{1}, \beta_{2}, \beta_{3}=$ koefisien korelasi

$\mathrm{X}_{1}=$ perceived usefulness

$\mathrm{X}_{2}=$ perceived ease of use

$\mathrm{X}_{3}=$ perceived availability

$\mathrm{e}=$ variable pengganggu

\section{PEMBAHASAN}

\subsection{Hasil Uji Validitas dan Reliabilitas}

Tabel 1. Validitas dan reliabilitas Perceived Usefulness (X1)

\begin{tabular}{|l|r|r|r|r|}
\multicolumn{7}{|c|}{ Item-Total Statistics } \\
\hline & $\begin{array}{c}\text { Scale Mean if } \\
\text { Item Deleted }\end{array}$ & $\begin{array}{c}\text { Scale } \\
\text { Variance if } \\
\text { Item Deleted }\end{array}$ & $\begin{array}{c}\text { Corrected } \\
\text { Item-Total } \\
\text { Correlation }\end{array}$ & $\begin{array}{c}\text { Cronbach's } \\
\text { Alpha if Item } \\
\text { Deleted }\end{array}$ \\
\hline X1.1 & 12.7234 & 5.422 & .652 & .884 \\
X1.2 & 12.9149 & 4.384 & .842 & .810 \\
X1.3 & 13.1064 & 3.967 & .754 & .854 \\
X1.4 & 13.1489 & 4.521 & .772 & .837 \\
\hline
\end{tabular}

Reliability Statistics

\begin{tabular}{|r|r|}
\hline $\begin{array}{c}\text { Cronbach's } \\
\text { Alpha }\end{array}$ & N of ltems \\
\hline .882 & 4 \\
\hline
\end{tabular}

Tabel 2. Validitas dan reliabilitas Perceived Ease of Use (X2)

Item-Total Statistics

\begin{tabular}{|c|c|c|c|c|c|c|}
\hline & $\begin{array}{l}\text { Scale Mean if } \\
\text { Item Deleted }\end{array}$ & $\begin{array}{c}\text { Scale } \\
\text { Variance if } \\
\text { Item Deleted }\end{array}$ & $\begin{array}{l}\text { Corrected } \\
\text { Item-Total } \\
\text { Correlation }\end{array}$ & $\begin{array}{c}\text { Cronbach's } \\
\text { Alpha if Item } \\
\text { Deleted }\end{array}$ & \multirow{2}{*}{\multicolumn{2}{|c|}{ Reliability Statistics }} \\
\hline $\mathrm{X} 2.1$ & 13.7447 & 2.977 & .647 & .864 & & \\
\hline$X 2.2$ & 13.0638 & 4.409 & .694 & .811 & Cronbach's & \\
\hline$\times 2.3$ & 13.1702 & 3.840 & .771 & .768 & Alpha & $\mathrm{N}$ of Items \\
\hline$\times 2.4$ & 13.1277 & 3.896 & .750 & .776 & .843 & 4 \\
\hline
\end{tabular}

Tabel 3. Validitas dan reliabilitas Perceived Availability (X3)

\begin{tabular}{|c|c|c|c|c|c|c|}
\hline \multicolumn{5}{|c|}{ Item-Total Statistics } & & \\
\hline & $\begin{array}{l}\text { Scale Mean if } \\
\text { Item Deleted }\end{array}$ & $\begin{array}{c}\text { Scale } \\
\text { Variance if } \\
\text { Item Deleted }\end{array}$ & $\begin{array}{l}\text { Corrected } \\
\text { Item-Total } \\
\text { Correlation }\end{array}$ & $\begin{array}{c}\text { Cronbach's } \\
\text { Alpha if Item } \\
\text { Deleted }\end{array}$ & \multirow{2}{*}{\multicolumn{2}{|c|}{ Reliability Statistics }} \\
\hline$\times 3.1$ & 10.1277 & 4.027 & .574 & .041 & & \\
\hline$\times 3.2$ & 9.5532 & 5.905 & .413 & .299 & Cronbach's & \\
\hline$\times 3.3$ & 9.5957 & 5.420 & .599 & .144 & Alpha & $\mathrm{N}$ of Items \\
\hline$\times 3.4$ & 10.0426 & 9.433 & -.209 & .801 & .485 & $\overline{4}$ \\
\hline
\end{tabular}

X3.4 tidak valid dan reliabel maka X3.4 d buang, dan dilakukan pengujian ulang

Item-Total Statistics

\begin{tabular}{|l|r|r|r|r|}
\hline & $\begin{array}{c}\text { Scale Mean if } \\
\text { Item Deleted }\end{array}$ & $\begin{array}{c}\text { Scale } \\
\text { Variance if } \\
\text { Item Deleted }\end{array}$ & $\begin{array}{c}\text { Corrected } \\
\text { Item-Total } \\
\text { Correlation }\end{array}$ & $\begin{array}{c}\text { Cronbach's } \\
\text { Alpha if Item } \\
\text { Deleted }\end{array}$ \\
\hline X3.1 & 7.0638 & 3.583 & .696 & .697 \\
X3.2 & 6.4894 & 5.125 & .603 & .772 \\
X3.3 & 6.5319 & 5.124 & .686 & .705 \\
\hline
\end{tabular}

Reliability Statistics

\begin{tabular}{|c|r|}
\hline $\begin{array}{c}\text { Cronbach's } \\
\text { Alpha }\end{array}$ & N of Items \\
\hline .801 & 3 \\
\hline
\end{tabular}


Tabel 4. Validitas dan reliabilitas Actual Usage (Y) Item-Total Statistics

\begin{tabular}{|l|r|r|r|r|}
\hline & $\begin{array}{c}\text { Scale Mean if } \\
\text { Item Deleted }\end{array}$ & $\begin{array}{c}\text { Scale } \\
\text { Variance if } \\
\text { Item Deleted }\end{array}$ & $\begin{array}{c}\text { Corrected } \\
\text { Item-Total } \\
\text { Correlation }\end{array}$ & $\begin{array}{c}\text { Cronbach's } \\
\text { Alpha if Item } \\
\text { Deleted }\end{array}$ \\
\hline Y1.1 & 10.8511 & 6.260 & .624 & .723 \\
Y1.2 & 11.1064 & 6.488 & .618 & .730 \\
Y1.3 & 11.1702 & 5.753 & .571 & .746 \\
Y1.4 & 11.8085 & 5.028 & .608 & .736 \\
\cline { 1 - 5 }
\end{tabular}

Dari tabel 1,2,3,4 terlihat hasil uji validitas untuk X1, X2, X3, dan Y diperoleh $\mathrm{r}$ hasil (corrected item-total correlation $)>\mathrm{r}$ tabel $(\mathrm{r}$ tabel $=0,2876)$. Dengan demikian maka variabel perceived usefulness, perceived ease of use, perceived availability, dan actual usage dinyatakan valid dan layak digunakan untuk penelitian.

Hasil uji reliabilitas nilai cronbach alpha X1, X2, X3, dan Y lebih besar dari $\mathrm{r}$ tabel (cronbach alpha>r tabel). Dengan demikian maka perceived usefulness, perceived ease of use, perceived availability, dan actual usage dinyatakan reliabel dan layak digunakan untuk penelitian.

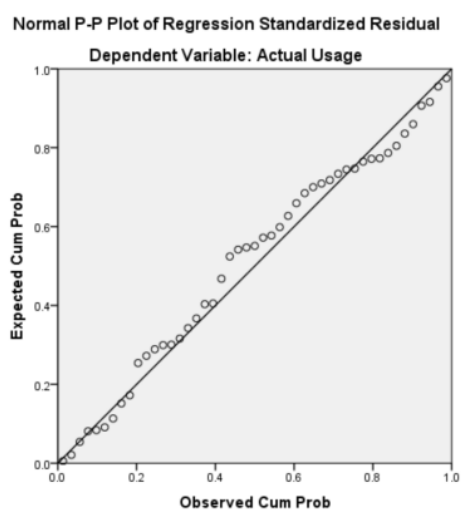

Gambar 2. Hasil uji normalitas

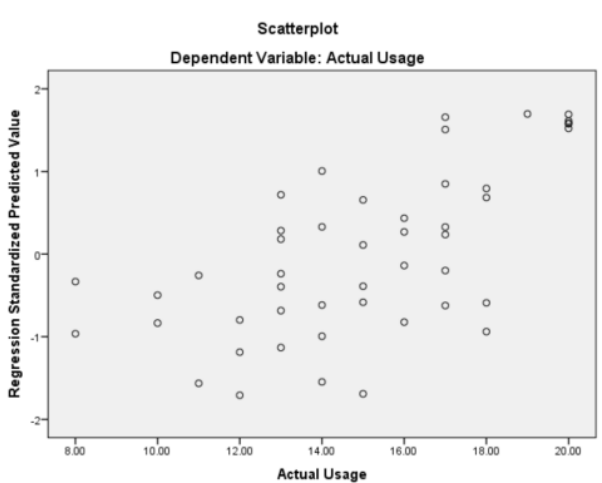

Gambar 3. Hasil uji heterokedastisitas

Dari gambar 2 dan 3 terlihat bahwa data terdistribusi mendekati garis normal dan menyebar secara acak. Pada table 5 juga terlihat bahwa nilai VIF untuk persamaan adalah lebih kecil dari 10, sehingga dapat dikatakan bahwa tidak ditemukan adanya masalah multikolinearitas.

Variabel X1, X2, dan X3 secara langsung mempengaruhi variabel Y.

Persamaan sub strukturalnya menjadi seperti ini:

$\mathrm{Y}=7.406-0,011 \mathrm{X} 1+0,118 \mathrm{X} 2+0,592 \mathrm{X} 3+\mathrm{C}_{1}$ 
Tabel 6. Model summary dan anova

Model Summary

\begin{tabular}{l|c|r|c|c|}
\hline Model & $R$ & R Square & $\begin{array}{c}\text { Adjusted R } \\
\text { Square }\end{array}$ & $\begin{array}{c}\text { Std. Error of } \\
\text { the Estimate }\end{array}$ \\
\hline 1 & $.642^{\mathrm{a}}$ & .412 & \multicolumn{3}{|c|}{.371} & 2.47705 \\
\hline
\end{tabular}
a. Predictors: (Constant), Perceived Availability, Perceived
Usefullness, Perceived Ease of Use
b. Dependent Variable: Actual Usage

ANOVA

\begin{tabular}{|ll|r|r|r|r|l|}
\hline Model & & \multicolumn{1}{c|}{$\begin{array}{c}\text { Sum of } \\
\text { Squares }\end{array}$} & \multicolumn{1}{c|}{ df } & Mean Square & F & Sig. \\
\hline 1 & Regression & 185.141 & 3 & 61.714 & 10.058 & $.000^{\mathrm{b}}$ \\
& Residual & 263.838 & 43 & 6.136 & & \\
& Total & 448.979 & 46 & & & \\
\hline
\end{tabular}

a. Dependent Variable: Actual Usage

b. Predictors: (Constant), Perceived Availability, Perceived Usefullness, Perceived Ease of

Use

Dari tabel 6 terlihat nilai Rsquare=0,412 yang berarti secara simultan variabel X1, X2 dan X3 memiliki kontribusi sebesar 41,2 persen dalam menjelaskan perubahan yang terjadi pada variabel Y sedangkan sisanya sebesar 58,8 persen dijelaskan oleh variabel lain di luar model.

Tabel 5. Nilai VIF untuk multikolinieritas Coefficients $^{a}$

\begin{tabular}{|c|c|c|c|c|c|c|c|c|}
\hline \multirow[b]{2}{*}{ Mode } & & \multicolumn{2}{|c|}{ Unstandardized Coefficients } & \multirow{2}{*}{$\begin{array}{c}\begin{array}{c}\text { Standardized } \\
\text { Coefficients }\end{array} \\
\text { Beta }\end{array}$} & \multirow[b]{2}{*}{$t$} & \multirow[b]{2}{*}{ Sig. } & \multicolumn{2}{|c|}{ Collinearity Statistics } \\
\hline & & $B$ & Std. Error & & & & Tolerance & VIF \\
\hline \multirow[t]{4}{*}{1} & (Constant) & 7.406 & 2.679 & & 2.765 & .008 & & \\
\hline & Perceived Usefullness & -.011 & .029 & -.048 & -.394 & .696 & .910 & 1.099 \\
\hline & Perceived Ease of Use & .118 & .174 & .096 & .679 & .501 & .688 & 1.454 \\
\hline & Perceived Availability & .592 & .142 & .582 & 4.159 & .000 & 697 & 1.434 \\
\hline
\end{tabular}

a. Dependent Variable: Actual Usage

T table $=2,01669 ;$ ada Coefficients (tabel 5) terlihat bahwa :

Variable perceived usefulness (X1) memiliki nilai t hitung -0,394 dengan nilai signifikan 0,696. Nilai $\mathrm{t}$ hitung $<\mathrm{t}$ table, sig $>0,05$; hipotesis 1 ditolak. Perceived usefulness tidak berpengaruh terhadap actual system usage SISAK Polsri. Mahasiswa menyadari bahwa SISAK Polsri berguna untuk kelancaran aktifitas administrasi akademik tetapi tidak berguna dalam kelancaran proses belajar mengajar. Hanya mahasiswa tertentu saja (perangkat kelas) yang memiliki akses untuk SISAK Polsri, sehingga mereka beranggapan SISAK Polsri tidak terlalu berpengaruh terhadap penggunaan yang sebenarnya.

Variable perceived ease of use (X2) memiliki nilai t hitung 0,679 dengan nilai signifikan 0,501. Nilai t hitung < t table, sig >0,05; hipotesis 2 ditolak. Perceived ease of use tidak berpengaruh terhadap actual system usage SISAK Polsri. Mahasiswa merasa mudah untuk mengakses dan menggunakan SISAK Polsri tetapi ada kelemahan yaitu SISAK Polsri hanya dapat diakses hanya dengan menggunakan jaringan internet internal (hotspot local). Hal inilah yang menyebabkan mahasiswa merasa tidak ada kemudahan dalam penggunaan yang sebenarnya bila mengakses SISAK Polsri tidak berada di kampus.

Variable perceived availability (X3) memiliki nilai t hitung 4,159 dengan nilai signifikan 0,000. Nilai t hitung > t table, sig <0,05; hipotesis 3 diterima. Perceived availability berpengaruh terhadap actual system usage SISAK Polsri. Mahasiswa merasa lancar dalam mengakses SISAK Polsri saat berada di kampus karena mereka sering menggunakan SISAK Polsri untuk presensi dosen.

\section{KESIMPULAN}

Penelitian ini menunjukkan hasil penerimaan terhadap sistem informasi akademik (SISAK) Politeknik Negeri Sriwijaya (Polsri) yang dilakukan dengan menggunakan model TAM (Technology Acceptance Model). Dari hasil pengujian didapatkan Variable perceived usefulness tidak berpengaruh terhadap actual system usage SISAK Polsri. Hal ini dikarenakan mahasiswa menyadari bahwa SISAK Polsri berguna untuk kelancaran aktifitas administrasi akademik tetapi tidak berguna dalam kelancaran proses belajar mengajar. Hanya mahasiswa tertentu saja (perangkat kelas) yang memiliki akses untuk SISAK Polsri, sehingga mereka beranggapan SISAK Polsri tidak terlalu berpengaruh terhadap penggunaan yang sebenarnya. 
Variable perceived ease of use tidak berpengaruh terhadap actual system usage SISAK Polsri. Mahasiswa merasa mudah untuk mengakses dan menggunakan SISAK Polsri tetapi ada kelemahan yaitu SISAK Polsri hanya dapat diakses hanya dengan menggunakan jaringan internet internal (hotspot local). Hal inilah yang menyebabkan mahasiswa merasa tidak ada kemudahan dalam penggunaan yang sebenarnya bila mengakses SISAK Polsri tidak berada di kampus. Variable perceived availability berpengaruh terhadap actual system usage SISAK Polsri. Mahasiswa merasa lancar dalam mengakses SISAK Polsri saat berada di kampus karena mereka sering menggunakan SISAK Polsri untuk presensi dosen.

\section{DAFTAR PUSTAKA}

[1] D. Ermawati dan H. Lutfi. 2015. Faktor-Faktor Yang Mempengaruhi Penerapan Sistem Informasi Layanan Akademik Berbasis Web (Studi kasus di IKPIA Perbanas). J. Akunt. dan Audit. 3 (1), 117.

[2] M. Hammer dan J. Champy. 1993. Reengineering the Corporation: A Manifesto for Business Revolution. London: Nicholas Brealey Publishing.

[3] M. Terziovski. 2015. Energizing Management Through Innovation and Entrepreneurship (Routledge Studies in Innovation, Organizations and Technology), 1st Editio. Melbourne: Routledge Taylor \& Frances Group.

[4] Sevima.com, "Manfaat Sistem Informasi Akademik Bagi Perguruan Tinggi \& Mahasiswa," 2018. [Online]. Available: https://sevima.com/manfaat-sistem-informasi-akademik-bagi-perguruantinggi-mahasiswa/. [Accessed: 16-Apr-2020].

[5] M. B. Suryawan dan Prihandoko. 2017. "Evaluasi Penerapan SIAKAD Politeknik Negeri Madiun," Citec J. 4 (3).

[6] P. D. Prof. Jogiyanto HM, Akt., MBA., 2007. Sistem Informasi Keperilakuan, 1st ed. Yogyakarta: Andi.

[7] A. Prihantara dan W. W. Winarno. 2015. Evaluasi Implementasi Sistem Informasi Kemahasiswaan Di Stkip Pgri Pacitan. J. Ilm. SISFOTENIKA. 5 (1), pp. 71-81

[8] M. Z. Uska, G. R. Dantes, dan M. Candiasa. 2016. Evaluasi Implementasi Kesuksesan Sistem Informasi Akademik ( SIAKAD ) Menggunakan ERP Success Model ( Studi Kasus STKIP Hamzanwadi Selong ). J. ILMU Komput. Indonesia. 1 (2).

[9] T. Handayani. 2013. Analisis Penerimaan Sistem Informasi Akademik Berbasis Web Menggunakan Technolohgy Acceptance Model ( TAM ) Dan Usability Studi Kasus Pada STTNAS Yogyakarta. Seminar Nasional Rekayasa Teknologi Industri dan Informasi.

[10] E. Yulianingsih dan B. Tujni. 2014. Evaluasi Penerimaan Pengguna Akhir Menggunakan Technology Acceptance Model Dan End User Computing Satisfaction Terhadap Penerapan ELearning Di Beberapa Perguruan Di Kota Palembang. Seminar Nasional Inovasi dan Trern (SNIT), pp. $127-129$.

[11] B. Suzanto dan I. Sidharta. 2015. Pengukuran End-User Computing Satisfaction Atas Penggunaan Sistem Informasi Akademik. J. Ekon. Bisnis Entrep. 9 (1), 16-28,

[12] W. DeLone dan E. McLean. 1992. The Quest for the Dependent Variable. Inf. Syst. Res. 3 (1), 6065 ,

[13] E. S. Riskadewi. 2014. Penerimaan Sistem Informasi Akademik Universitas Airlangga Cyber Campus (UACC) Pada Dosen Fisip Universitas Airlangga. J. Univ. Airlangga, 3, 150-171,

[14] F. D. Davis,. 1989. Perceived Usefulness, Perceived Ease Of Use And User Acceptance. MIS Q., 13 (3), 319-339,

[15] A. Qiantori, A. B. Sutiono, H. Suwa, dan T. Ohta. 2010. 3G mobile TV acceptance in Indonesia. Proc. - 6th Int. Conf. Wirel. Mob. Commun. ICWMC 2010, 526-531

[16] D. H. Shin. 2007. User acceptance of mobile Internet: Implication for convergence technologies. Interact. Comput. 19 (4), 472-483, 
[17] S.-J. Hong dan Y. T. Kar. 2013. Understanding the Adoption of Multipurpose Understanding The Case of Mobile Data Services. 17 (2), 162-179,

[18] Ayokuliah.id, "Sistem Informasi Akademik apa sih?," 2018. [Online]. Available: https://ayokuliah.id/artikel/tips-kuliah/sistem-informasi-akademik-pengertian/. [Accessed: 16Apr-2020].

[19] D. Priyatno. 2013. Mandiri Belajar Analisis Data Dengan SPSS. Jakarta: MediaKom.

[20] S. Uma. 2006. Metodelogi Penelitian Untuk Bisnis, 4th ed. Jakarta: Salemba Empat,

[21] S. Yamin. 2009. SPSS Complete. Teknik Analisis Statistik Terlengkap dengan Software SPSS. Jakarta: Salemba Infotek. 